УДК 378.147.88

JEL A22, B12, I20

DOI 10.31375/2226-1915-2021-3-104-114

\title{
DUAL EDUCATION AS A WAY TO SOLVE MODERN PROBLEMS OF UKRAINIAN HIGHER EDUCATIONAL INSTITUTIONS
}

\author{
Olga K. Afanasieva \\ $\mathrm{PhD}$ in Economics, docent of the Department «Management and Marketing» \\ Olena A. Shakhova \\ Master's students of the specialty 073 «Management@, \\ Odessa National Maritime University, Odessa, Ukraine
}

\begin{abstract}
High quality education is one of the main aspects that enables graduates to be competitive in the labor market. Competitiveness consists not only of professional knowledge and skills, but also of different qualities, such as resistance to stress, initiative, sociability, application of knowledge in practice and skills for self-organization, just to name a few. Contributing to the development of these qualities creates new difficulties for higher educational institutions (HEI), since in order to do this effectively, it is necessary to use a modern material and technical base and involve first-class specialists with practical experience.

The problems of higher education faced by Ukrainian HEI today do not allow students to fulfill their potential in their own universities. Moreover, the qualifications of students after graduation are often not good enough to meet the needs of employers. One of the ways to make the education system more effective for both students and higher institutions is a dual education system.

This reserch aims to describe the model of dual education as a tool to solve the main problems faced by Ukrainian universities. The article reveals the differences between the traditional model of education and dual one: acquisition of technical skills, development of critical thinking, learning through experience, and reflection on work practice, solving problems in the work environment, and is thus centered around real-life projects. Also the study shows the approaches to the organization of this type of education, which are inherent in different countries, as well as the advantages that allow dual education to increase the competitiveness of universities in the country and, as a result, their graduates.

Based on the experience of Germany, a world leader in the organization of this model of education through the analysis of its basic elements, an algorithm of implementation of concept of a dual education in Ukrainian HEI was developed. Proposed main steps that universities should take to implement dual education (such as creation of a dual education department at universities; forecast of sectoral and regional needs; search for enterprises that are interested in the dual form of education; selection of students for vacant places for dual education; signing a tripartite agreement; curriculum development to combine practical and theoretical knowledge; issuance of an order on the organization of dual education and referral of students to the enterprise during dates; regular monitoring of student work at the enterprise; control of learning outcomes) will allow them to improve the quality of skills of graduates, as well as create more effective relationships with local enterprises and the state.
\end{abstract}

Keywords: dual education, university competitiveness, traditional education, world experience of dual education. 
DEVELOPMENT OF MANAGEMENT

AND ENTREPRENEURSHIP METHODS

ON TRANSPORT, № 3 (76), 2021
РОЗВИТОК МЕТОДІВ

УПРАВЛІННЯ ТА ГОСПОДАРЮВАННЯ

НА ТРАНСПОРТІ, № 3 (76), 2021

\section{УДК 378.147.88 \\ JEL A22, B12, I20 \\ DOI 10.31375/2226-1915-2021-3-104-114 \\ ДУАЛЬНА ОСВІТА ЯК ШЛЯХ ВИРІШЕННЯ СУЧАСНИХ ПРОБЛЕМ УКРАЇНСЬКИХ ЗАКЛАДІВ ВИЩОЇ ОСВІТИ}

О.К. Афанасьєва

к.е.н., доцент кафедры «Менеджмент и маркетинг» О.А. Шахова

магистр специальности 073 «Менеджмент»

Одеський національний морський університет, Одеса, Украӥна

Анотація. Високоякісна освіта є одним із основних аспектів, який дає можливість випускникам бути конкурентоспроможними на ринку праці. Проблеми вищої освіти, з якими сьогодні стикаються украйнські заклади вищоі освіти (3ВО), не дають можливості студентам реалізувати свій потениіал у стінах власних університетів. Більш того, кваліфікації, якими володіють студенти по завершенню університету, часто не є достатніми аби задовольнити потреби роботодавиів. Одним із способів зробити систему освіти більш ефективною як для студентів, так $і$ для 3 ВО є концепиія дуальної освіти.

Дане дослідження направлено на опис моделі дуальної освіти в якості інструмента, щуо дозволяє вирішити основні проблеми, з якими зіштовхуються українські університети. У статті розкрита різниия між традичійною моделлю освіти $і$ дуальною, підходи до організаціі даного виду навчання, щзо притаманні різним країнам, а також переваги, щзо дозволяють дуальній освіті підвищувати конкурентоспроможність університетів в країні, $i, \quad я \kappa$ результат, їхніх випускників.

Спираючись на досвід Німеччини, яка $\epsilon$ світовим лідером в організації даної моделі навчання, було розроблено алгоритм впровадження концепції дуальної освіти в українські ЗВО. Запропоновані основні кроки, які мають вжити університети для впровадження дуальної освіти, що допоможе дозволити їм підвищити якість підготовки випускників, а також створити більш ефективні стосунки із регіональними підприємствами і державою.

Ключові слова: дуальна освіта, традиційна освіта, конкурентоспроможність університету, світовий досвід дуальної освіти.

(C) Афанасьєва О.К., Шахова О.А., 2021
УДК 378.147.88

JEL A22, B12, I20

DOI 10.31375/2226-1915-2021-3-104-114

\section{ДУАЛЬНОЕ ОБРАЗОВАНИЕ КАК ПУТЬ РЕШЕНИЯ СОВРЕМЕННЫХ ПРОБЛЕМ УКРАИНСКИХ ЗАВЕДЕНИЙ ВЫСШЕГО ОБРАЗОВАНИЯ}

\section{О.К. Афанасьєва}

к.е.н., доцент кафедры «Менеджмент и маркетинг» Е.А. Шахова

магистр специальности 073 «Менеджмент»

Одесский национальній морской университет, Одесса, Украина

Аннотация. Высококачественное образование является одним из основных аспектов, который дает возможность выпускникам быть конкурентоспособными на рынке труда. Проблемы высшего образования, с которыми сегодня сталкиваются украинские заведения высшего образования (3ВО), не дают возможности студентам реализовать свой потенциал в стенах собственных университетах. Более того, квалификаций, которыми обладают студенты по окончанию университетов, часто недостаточно для того, чтобы удовлетворить потребности работодателей. Одним из способов сделать систему образования более эффективной как для студентов, так и для $3 В О$ является концепция дуального образования.

Данное исследование направлено на описание модели дуального образования. В статье раскрыта разница между традиционной моделью образования и дуальной, подходы к организачии данного вида обучения, присущие разным странам, а также преимущества, позволяюшие дуальной системе повышать конкурентоспособность университетов, $и$, как результат, их выпускников.

Опираясь на опьт Германии, являющейся мировым лидером в организации данной модели обучения, был разработан алгоритм внедрения концепции дуального образования в украинские ЗВО. Предложены основные шаги, которые стоит предпринять университетам для внедрения дуальной системы образования, что сможет позволить им повысить качество подготовки выпускников, а также создать более эффективные отнотения с региональными предприятиями и государством.

Ключевые слова: дуальное образование, традииионное образование, конкурентоспособность университета, мировой опыт дуального образования. 
Problem statement. Education, which creates conditions and gives opportunities for shaping awareness of a young individual as a professional in a chosen field, creates intellectual, scientific, and creative potential of society, has always been a fundamental type of investment in a human capital. Unfortunately, the current format of the educational process in Ukraine is not focused on the comprehensive development of the individual andmeeting the needs of society and the labor market with competitive, competent and responsible professionals.

The main problems of the higher education system in Ukraine, which are the use of Soviet technology, lack of social responsibility, aging teaching staff and public funding [1] have become obstacles through which Ukrainian education can not meet the needs of its consumers. Addressing these issues is a key factor in moving to a more efficient higher education system, aimed at training highly qualified professionals who can contribute to the country's economic and social development. And although each of these problems can be solved with the help of separate levers, one of the ways to address all these problems is the implementation of dual education in higher education. This new approach to the system of vocational education that will ensure high-quality training of highly qualified specialists of the future.

Review of the last research and publications. Dual education is a specific system of education, which is aimed at a systematic combination of the benefits of learning in the enterprise and learning at institution [2]. The term «dual education» implies that two institutions, namely vocational schools and enterprises, cooperate in order to qualify students for a certain profession [3]. As the practice of the European education system shows, this system is a product of cooperation between educational organizations and employers on the successful professional and social adaptation of the future specialist. The student is included on the production process as an employee of an enterprise already in the early stages of the learning process [4].

The dual model of educationis about the involvement of enterprises in the process of training, which comeswith a very significant cost for them associated with the training of employees. However, they are engaged because of the understanding that the cost of quality vocational education is a reliable contribution of capital [5]. At the same time, they become interested not only in learning outcomes, but also in the content of learning, its organization.

Dual education allows students not only to develop the skills needed in the labor market, but also allows the state to maintain a balance in the training of individuals in different professions [6]. Creating a harmonious relationship between higher education and the needs of the labor market allows not only to ensure a high level of qualification of graduates, save money for the company, but also increase the employment of future professionals and make them more competitive in the labor market [7].

In addition to the use of Soviet technology, lack of social responsibility, aging teaching staff and dependence on public funding, dual education can address a number of other problems of the 
Ukrainian higher education system. These include the unwillingness of graduates to work in the area they chose to study, dissatisfaction with quality of education by employers, which leads to the need for additional training in the workplace, expanding the system of training in business entities, and lack of necessary experience of students to get a job for the first time [8]. The labor market that is being shaped in conditions dictated by globalization needs professionals who can work in a multidisciplinary environment, know how to work in a team, and have developed communication skills.

Dual education is one of the methods that allows universities to solve their problems and helps students to achieve the competencies mentioned above [9]. With this system, students cease to be passive consumers of information and start taking an active part in their own education. Moreover, dual education allows young people to more easily adapt to work relationships and adult life. In addition, this model has many other benefits. It leads to a reduction in crime, social cohesion, improved health, solidarity between generations, increased life satisfaction, and higher individual motivation [10].

The goal of the study. This study is directed to understanding the concept of dual education system in comparising with traditional education, learning about the leading wold experience and examples of dual education system implementation, and based on this information creating recommendations for implementation of dual education system in Ukrainian universities.
Research summary. Dual education is very different from the traditional model of learning. This statement has been confirmed by many researchers, including a researcher Dernova. Unlike traditional learning, the dual model involves not only the acquisition of technical skills, but also the development of critical thinking, learning through experience, and reflection on work practice. Moreover, dual education views learning as the result of action and problem solving in the work environment, and is thus centered around reallife projects and problems [11]. Some other differences between dual education and traditional model of learning are described in a Table.

The criteria provided in the table clearly highlight all the competitive advantages that dual education has compared to a traditional model of learning. First, by engaging in practical tasks most of the time, students learn to operate in a reallife working environment and deal with existing challenges in the field.

Second, the involvement of many stakeholders in the process of educational and regulatory framework development rather than just relying on state and university allows to create a holistic approach to teaching and learning.

Third, considering the importance of corporate culture in the operations of any enterprise, the ability to immerse in it through a dual education system can help students easier and faster adapt to a work environment. 
DEVELOPMENT OF MANAGEMENT AND ENTREPRENEURSHIP METHODS ON TRANSPORT, № 3 (76), 2021
РОЗВИТОК МЕТОДІВ

УПРАВЛІННЯ ТА ГОСПОДАРЮВАННЯ

НА ТРАНСПОРТІ, № 3 (76), 2021

Comparison of dual and traditional models of education

Table

\begin{tabular}{|l|l|l|}
\hline \multicolumn{1}{|c|}{ Comparison Criterion } & \multicolumn{1}{|c|}{ Dual Education } & \multicolumn{1}{|c|}{ Traditional Education } \\
\hline $\begin{array}{l}\text { Ratio of theory and } \\
\text { practice }\end{array}$ & \multicolumn{1}{|c|}{$30 / 70$} & \multicolumn{1}{c|}{$70 / 30$} \\
\hline $\begin{array}{l}\text { Development of the } \\
\text { educational and regulatory } \\
\text { framework }\end{array}$ & $\begin{array}{l}\text { All subjects of education } \\
\text { take part in the process: the } \\
\text { state, employers, employ- } \\
\text { ers' associations, educatio- } \\
\text { nal institutions, and trade } \\
\text { unions }\end{array}$ & $\begin{array}{l}\text { Carried out by the state and } \\
\text { the educational institution }\end{array}$ \\
\hline $\begin{array}{l}\text { Familiarity with the cor- } \\
\text { porate culture of the } \\
\text { company }\end{array}$ & $\begin{array}{l}\text { Allows students to get } \\
\text { acquainted with the real } \\
\text { corporate culture at the } \\
\text { enterprise }\end{array}$ & $\begin{array}{l}\text { The short duration of } \\
\text { internships does not allow } \\
\text { to understand the corporate } \\
\text { culture of the organization }\end{array}$ \\
\hline Coursework & $\begin{array}{l}\text { Topics of coursework and } \\
\text { individual projects are } \\
\text { focused on potential needs } \\
\text { of the enterprise }\end{array}$ & $\begin{array}{l}\text { Courseworks are often a } \\
\text { formality that don't have a } \\
\text { practical value }\end{array}$ \\
\hline $\begin{array}{l}\text { Awareness and choice } \\
\text { of occupation }\end{array}$ & $\begin{array}{l}\text { Carried out before gradua- } \\
\text { tion or from the first year } \\
\text { of study at the institution }\end{array}$ & $\begin{array}{l}\text { Carried out in the 3rd year } \\
\text { of study when an internship } \\
\text { at the enterprises begins }\end{array}$ \\
\hline
\end{tabular}

Source: Own elaboration using [2-3; 11; 12]

And, last but not least, by immersing in the field right after entering the university, students can not only gain work experience but, what is most important, they get to understand whether it is the area they see themselves working in the future. Completing an internship after the $3^{\text {rd }}$ year of studies within a traditional education model makes it difficult for students to change the direction of their professional path because they are already close tograduation.

The constant need to update technologies and insufficient material and technical base in Ukrainian higher education institutions [12] confirms the relevance of the dual model of education in
Ukraine. This system of education positively contributes to the development of the system of continuing education, creating comfortable conditions for staffing, scientific and methodological and logistical support of educational institutions.

The use of foreign experience is a necessary component of the effective implementation of dual education in Ukraine.

There are various systems of dual education around the world. To differentiate these systems, the role of the state can be taken into account. For example, in market economy systems, which include countries such as the United Sta- 
tes, Great Britain and Japan, the state does not participate in dual education. In Germany, Austria and Switzerland, where there is a mixed economy, the state sets the rules for dual education and the private sector is responsible for providing training. In the system of traditional economy, for example, in France, the state plans, organizes and controls dual education [13].

Germany is considered to be a recognized leader in the organization of dual education, characterized by a developed institution of mentoring, practiceoriented training and active participation of enterprises in training. The experience of this country serves as a model for the entire European Union. The duration of training, depending on the specialty varies from 2 to 3,5 years [14]. When replacing each training place, a competitive selection is arranged, because the number of applicants is much bigger than the declared places.

Not every enterpise can teach students. To do this, it must have a permit to conduct educational activities, which can be obtained from the Chamber of Commerce and Industry, proving that the company meets all the necessary requirements. [14]. As part of education, most of the time is spent at the enterprise (3-4 days a week). For understanding the theory, students are given 1-2 days a week (8-12 hours) at university. The company pays the student a salary in the amount corresponding to less than the salary of a certified specialist [15].
German approach to dual education has become an example for other European countries for several reasons. First, its broad goal that views training as a means to achieve economic, social and individual goals. Second, the main purpose of training is to create skilled workers with flexible qualifications. Third, vocational training is a partnership between government and the business community based on co-financing. Special codifications of quality standards and qualifications of teachers and teaching staff are another aspect that allows this training system to be so effective. Moreover, the social acceptance of this type of training is one of the key aspects of its success [16].

Foreign experience of dual education provides an opportunity to create a specific plan for its effective implementation in Ukrainian free economic zones. This process can be divided into 9 stages (fig.).

1. Creation of a department aimed at organizing the dual education at universities. This initiative will simplify and establish the process of communication between higher institutions, potential employers, and students. Given the number of processes that need to be managed to reach as many businesses and students as possible, including analyzing labor market needs, finding businesses for cooperation, raising awareness of this form of learning among students, and helping to coordinate their learning, there is a need for a more efficient organization of these processes through a specific department. 


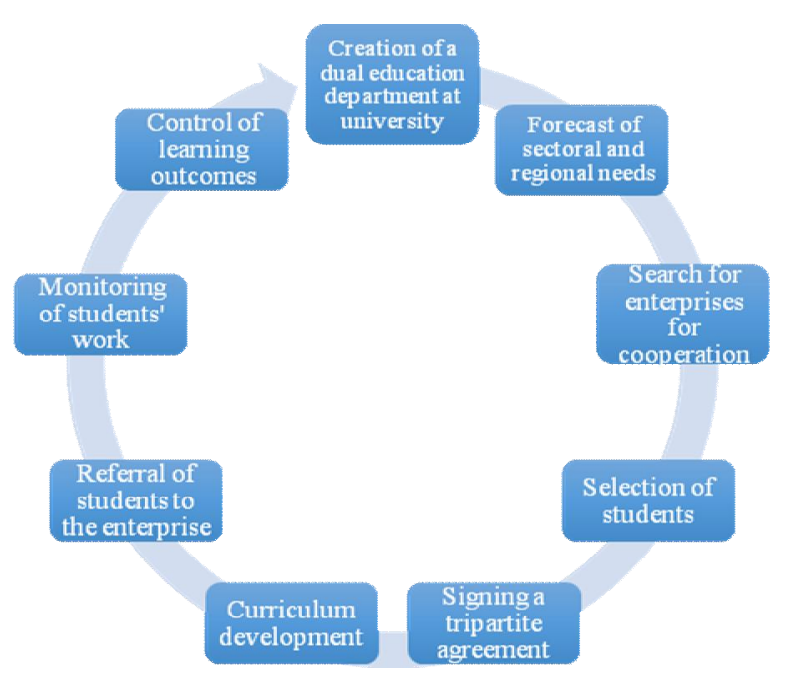

Fig. Steps to implementing dual education in Ukrainian universities

Source: Own elaboration using [3; 8; 10-15]

2. Forecast of sectoral and regional needs. High-quality forecasting of sectoral and regional needs is one of the key aspects of the successful functioning of the dual model of education, as it allows to determine the agreed focus of regional authorities, employers, and the educational community on training and further build appropriate training programs. To ensure the effectiveness of the process of forecasting and planning training needs, a method based on statistical analysis of staff turnover will be developed, which allows to identify the needs of the enterprise in specialists in different periods.

3. Search for enterprises that are interested in the dual form of education according to the forecast of needs in specialists acquired during the second stage. During this stage, the dual education department should involve many communication channels to reach as many employers as possible. These may include social networks, job search sites, alumni networks, conferences, etc.

4. Selection of students for vacant places for dual education. This selection can take place only with the support of the department and with the participation of the enterpise, which has the opportunity to select students who are best suited for certain positions in the organization.

5. Signing a tripartite agreement between a university, student, and enterprice. The tripartite agreement contains information on the subjects, purpose, terms of training, type of employment, and expected learning outcomes of the learner in the workplace, working conditions and working hours, rights and obligations of the parties to the agreement, terms of termination and financial obligations.

6. Curriculum development. The dual training program must meet the direction of production activities and the 
needs of a particular enterprise and take into account the specifics of job responsibilities in the workplace. The enterprise provides the applicants with practical and theoretical knowledge of compulsory and elective disciplines of the professional cycle of the educational training program or their components, within the scope of its own production activities. At the same time, the program must be coordinated with the disciplines studied at universities.

7. Issuance of an order on the organization of dual education and referral of students to the enterprise during dates specified by the Tripartite Agreement.

8. Regular monitoring of student work at the enterprise. Through feedback forms completed by both student supervisors and students themselves, the dual education department is able to assess student progress and make adjustments to future contracts and programs with other enterprises to improve their effectiveness.

9. Control of learning outcomes. Creation of practices together with the enterprise, which allow to assess the progress of the student that were acquired both during theoretical learning at university and in the enterprise.

Conclusions. Modern problems of Ukrainian higher education need to be solved by methods that will allow graduates to become more competitive in the international labor market. As foreign experience shows, one of the most effective ways to meet the needs of employers and help students develop the skills that are needed in the workplace is a dual form of education. The experience of the German system of this form of education allowed to develop a model of implementation of dual education in Ukrainian universities, which consists of nine main steps. Using this model can not only improve the effectiveness of student learning, but also establish connections and improve relations between higher educational institutions, businesses, and the state.

However, effective implementation of this model is almost impposible without a further research that examines in detail the context of Ukrainian higher education system, its strengths, opportunities, and weaknesses. Moreover, by conducting studies that are directed at estimating costs of implementing this model of dual education for different stakeholders, it will be possible to achieve quantitative analysis that will allow measure university competitiveness on both Ukrainian and global educational markets.

\section{REFERENCES}

1. Valdshmit, I.M., \& Gaidei, M.O. (2014). Osnovni problemi sistemi vishhoyi osvi ti $v$ Ukrayini` ta shlyakhi yiyi moderni zaczi yi [The main problems of the higher education system in Ukraine and ways to modernize it]. Economics and Government, 6, 152-155. Retrieved from http://www.economy.in.ual pdf/ 6_2014/35.pdf [in Ukrainian]. 
2. Vem'yan, V.G., \& Ter-Ovanes'yan, V.G. (2015). Dual'na forma profesijnoi osviti yak umova efektivnogo rishennya zavdan' modernizacii osviti [Dual form of vocational education as a condition for effective solution to the task of modernization of education]. Psihologiya: real'nist' i perspektivi, 5, 29-33. Retrieved from https://openarchive.nure.ua/bitstream/ document/ 7811/ 1/ ДУАЛЬНА\%20ФОРМА\%2ОПРОФЕСІЙНОЇ\%20ОСВІТИ\% 20ЯК\% 20 УМОВА\% 20ЕФЕКТИВНОГО \%2ОРІШЕННЯ\%20ЗАВДАНЬ\% 20 МОДЕРНІЗАЦІЇ\%20ОСВІТИ.pdf [in Ukrainian].

3. Greinert, W.D. (1995). Podvi jna sistema profesi jnogo navchannya u Federativni’j Respubli'czi' Ni'mechchina [Das Duale System der Berufsausbildung in der Bundesrepublik Deutschland]. Deutsche Gesellschaft furTechnische Zusammenarbeit [in German].

4. Yugfeld, E.A. (2014). Dual naya model obucheniya kak osnova mekhanizma vzaimodejstviya obrazovatel 'ny 'kh uchrezhdenij i predpriyatij [Dual model of education as a foundation of cooperation between educational institutions and enterprises]. Retrieved from https://www.daemmt.odesa.ual downloads/ article_sample.pdf [in Russian].

5. Smith, A. (2007). Dosli 'dzhennya pro prirodu $i$ 'prichini bagatstva narodi $v$ [Research on the nature and causes of the wealth of nations]. Eksmo [in Russian].

6. Pominchuk, S.H. (2019). Professional orientation in the system of introduction of the dual form of education. Young Scientist, 8(72), 339-344. doi: 10.32839/23045809/201987271 [in English]

7. Krymchak, L. Yu. (2019). The system of dual education as a condition for quality training of competitive professionals for the labor market in Ukraine. Innovatsijna pedahohika, 11(2), 83-86. Retrieved from http://www. innovpedagogy.od.ua/archives/2019/11/part_2/11-2_2019.pdf [in Ukrainian].

8. Gerlyand, T., Drozich, I., Kulalaєva, N., Romanova, G., \& Shimanovs'kij, M. (2019). Organization of dual form of education in vocational (vocational and technical) educational institutions. Polissya [in Ukrainian].

9. Craig K.C., \&Voglewede P.A. (2010). Vyshcha osvita bahatoprofilnykh inzhenernykh system: Mahistr inzhenernykh nauk $z$ mekhatroniky[Multidisciplinary engineering systems graduate education: Master of engineering in mechatronics]. IEEE Conference on Transforming Engineering Education: Creating Interdisciplinary skills for Complex Global Environment, 1-10. doi: 10.1109/TEE.2010.5508819.

10. Cedefop. (2011). Perevagi profesi jnoyi osvi ti ta navchannya [The benefits of vocational education and training]. Luxembourg: Publications Office. Retrieved from http://www.cedefop.europa.eu/EN/Files/5510_en.pdf.

11. Dernova, M.G. (2014). Podvi jna model sistemi vishhoyi osvi ti doroslikh: yevropejs kij dosvi'd [Dual model of higher education system of adults: European expeirence]. Education of adults: Theory, Experience, Perspectives, 2(9), 137-145. [in Ukrainian]. 
12. Kurchev, V.M., Lomeiko, O.P. (2018). Vprovadzhennya dual nogo navchannya $v$ osvitni $\dddot{j}$ proczes. Udoskonalennya osvi'tn ovikhovnogo proczesu $v$ navchal nomu zakladi' [Introduction of dual learning in the educational process. Improving the educational process in an educational institution]. In Zbi 'rnik naukovo-metodichnikh pracz' (pp. 4-9). [in Ukrainian].

13. Fürstenau, B., Pilz, M., \& Gonon, P. (2014). Dualna systema profesiinoi osvity ta navchannia $v$ Nimechchyni - shcho mozhna diznatysia pro osvitu dlia (inshykh) profesii [The dual system of vocational education and training in Germany - what can be learnt about education for (other) professions]. In Billett, S., Harteis, S., \& Gruber, H. (Eds.) International Handbook of Research in Professional and Practice-based Learning (pp. 427-459). Springer. doi: 10.1007/978-94-017-8902-8_16.

14. Boichevs'ka, I. (2014). Rol' systemy dual'noi osvity u profesiinii pidhotovtsi molodi $u$ Nimechchyni [The role of the dual education system in the training of young people in Germany]. Retrieved from: https://nmcpto.sumy.ua/wpcontent/uploads/2017/04/Дуальна-система-Німеччини.pdf [in Ukrainian]

15. Anikeev, A.A. (2012). Suchasna struktura osvi ti v Ni 'mechchini` [Modern educational structure in Germany. Alma mater, 3, 67-68 [in Ukrainian].

16. Euler, D. (2013). Podviina systema profesiinoho navchannia Nimechchyny: Model dlia inshykh krain? [Germany's dual vocational training system: A model for other countries?]. Bertelsmann Stiftung.

\section{СПИСОК ЛІТЕРАТУРИ}

1. Вальдшміт I.М., Гайдей М.О. Основні проблеми системи вищої освіти в Украӥні та иляхи ї̈ модернізачії // Економіка та держава. 2014. №6. C. $152-155$.

2. Вем'ян В.Г. Дуальна форма професійної освіти як умова ефективного рімення завдань модернізації освіти // Психологія: реальність $i$ перспективи. 2015. № 5. С. 29-34.

3. Greinert, W.D. Das Duale System der Berufsausbildung in der Bundesrepublik Deutschland // Deutsche Gesellschaft fur Technische Zusammenarbeit. 1995.

4. Югфельд Е.А. Дуальная модель обучения как основа механизма взаимодействия образовательных учреждений и предприятий // Актуальные вопросы современного российского образования. 2014. URL: https://s.econf.rae.ru/pdf/2014/09/3687.pdf.

5. Смит А. Исследование о природе и причинах богатства народов. Москва: Эксмо, 2007. 960 c.

6. Pominchuk S. H. Professional orientation in the system of introduction of the dual form of education // Young Scientist. 2019. № 72. C. 330-344.

7. Кримчак Л. Ю. Система дуальної освіти як умова якісної підготовки конкурентоспроможних професіоналів на ринку праиі Украӥни // Інновачійна педагогіка. 2019. № 2. С. 83-86. 
8. Герлянд, Т., Дрозіч, І., Кулаєва, Н. Організачія дуальної форми навчання у закладаї професійної (професійно-технічної) освіти. Житомир: Полісся, 2019. $304 c$.

9. Craig K. Multidisciplinary Engineering Systems Graduate Education: Master of Engineering in Mechatronics // 2010 IEEE Transforming Engineering Education: Creating Interdisciplinary Skills for Complex Global Environments. 2010. C. 1-14.

10. Cedefop. The benefits of vocational education and training // Publications Office of the European Union. 2011. URL: https://www.cedefop.europa.eu/ files/5510_en.pdf.

11. Дернова М.Г. Дуальна модель вищуої професійної освіти дорослих: європейський досвід. // Освіта дорослих: теорія, досвід, перспективи. 2014. № 2. C. 137-145.

12. Кюрчев В. М. Впровадження дуального навчання в освітній процес // Збірник науково-методичних працьь «Удосконалення освітньо-виховного проиесу в навчальному закладі». 2018. C. 4-9.

13. Fürstenau, B., Pilz, M., Gonon, P. The dual system of vocational education and training in Germany - what can be learnt about education for (other) professions. // International Handbook of Research in Professional and Practice-based Learning. New York: Springer, 2014. C. 427-459.

14. Бойчевська I. Роль системи дуальної освіти у професійній підготовці молоді Німеччини // Порівняльно-педагогічні студії. 2014.

15. Анікеев А. А. Сучасна структура освіти науки в Німеччині // Alma mater. № 3. 2012. C. 67-68.

16. Euler D. Germany's dual vocational training system: a model for other countries? Gütersloh: Bertelsmann Stiftung. 2013. 79 c.

Article received 24.09.2021

Reference a JournalArtic: Afanasieva Olga K. \& Shakhova Olena A. (2021). Dual education as a way to solve modern problems of Ukrainian higher educational institutions. Development of management and entrepreneurship methods on transport. 3 (76), 104-114. DOI 10.31375/2226-1915-2021-3-104-114.

Стаття надійшла до редакції 24.09.2021

Посилання на статтю: Афанасьєва О.К., Шахова О.А. дуальна освіта як шлях вирішення сучасних проблем українських закладів вищої освіти // Розвиток методів управління та господарювання на транспорті: Зб. наук. праць, 2021. № 3 (76). С. 104-114. DOI 10.31375/2226-1915-2021-3-104-114. 